Article

\title{
Microsatellites in the Endangered Species Dyckia distachya (Bromeliaceae) and Cross-Amplification in Other Bromeliads
}

\author{
Camila M. Zanella ${ }^{1, \dagger}$, Aline Janke ${ }^{1, \dagger}$, Gecele M. Paggi ${ }^{2}$, Márcia Goetze ${ }^{1}$, Mauricio S. Reis ${ }^{3}$ and \\ Fernanda Bered ${ }^{1, *}$
}

1 Genetics Department, Biosciences Institute/Federal University of Rio Grande do Sul State - UFRGS, CEP 91501-970, Porto Alegre, RS, Brazil; E-Mails: milamzanella@yahoo.com.br (C.M.Z.); alinejanke@gmail.com (A.J.); marciagoetze@yahoo.com.br (M.G.)

2 Biological Sciences, Pantanal Campus/Federal University of Mato Grosso do Sul State - UFMS, CP 252, CEP 79304-902, Corumbá, MS, Brazil; E-Mail: gecele.paggi@ufms.br

3 Crop Sciences Department, Agronomy Center, Federal University of Santa Catarina State - UFSC, CP 476, CEP 88040-900, Florianópolis, SC, Brazil; E-Mail: msedrez@gmail.com

$\dagger$ These authors contributed equally to this work.

* Author to whom correspondence should be addressed; E-Mail: fernanda.bered@ufrgs.br; Tel.: +55-51-33086742; Fax: +55-51-33087311.

Received: 13 October 2012; in revised form: 13 November 2012 / Accepted: 16 November 2012 / Published: 27 November 2012

\begin{abstract}
Microsatellite markers were isolated in Dyckia distachya, an endangered bromeliad from southern Brazil, which will be useful to assess the population genetic structure and reproductive success in introduced and natural populations of this species. Twenty microsatellite loci were developed from an enriched genomic library, and nine of these were amplified. The loci were characterized in 43 individuals from introduced and wild $D$. distachya populations. All nine loci were polymorphic, with four to ten alleles per locus. In an introduced population the observed and expected heterozygosities ranged from $0.136-0.667$ and $0.543-0.877$, respectively, while in a wild population it ranged from 0.000 to 0.895 and from 0.050 to 0.811 , respectively. The development of these microsatellite markers will contribute to investigations of the reproductive potential and viability of introduced populations of $D$. distachya as well as the single known wild population. Cross-amplification in other Bromeliaceae species was successful, with high rates in four loci, demonstrating the applicability of these microsatellite markers in other taxa.
\end{abstract}


Keywords: Bromeliad; endemism; introduction; rheophytic species; SSR

\section{Introduction}

Dyckia distachya Hassler is a rare, endemic bromeliad (subfamily Pitcairnioideae) with a rupicolous, rheophytic habit that lives on riverbanks along the rapids of the Pelotas and Uruguay Rivers in southern Brazil [1]. The species is adapted to extreme variations of low and high water periods, and is characterized by high clonal reproduction [2,3]. According to Reitz [1] and Reis et al. [2], D. distachya is facing extinction due to increased hydroelectric construction along the rivers. Originally, eight wild populations of $D$. distachya were known along the Uruguay and Pelotas Rivers. Currently, only one wild population is known, located in Salto do Yucumã in Turvo State Park, Derrubadas, Rio Grande do Sul State, which is on the border between Brazil and Argentina. Therefore, D. distachya is on the Official List of Brazilian Endangered Species [4]. During Barra Grande hydroelectric construction, some $D$. distachya populations were rescued and conserved ex situ. However, the process occurred rapidly, without appropriate planning regarding the genetic structure of the populations. Initially, the plants were kept in nurseries before being introduced in environments similar to their origin. In addition to the long-term monitoring of introduced populations, knowledge of the genetic diversity of these populations is needed so that they can be managed appropriately and the success of the introduction is ensured.

Here, we report the isolation and characterization of a set of nine microsatellite loci for $D$. distachya in one introduced population and in the only one known wild population. The cross-amplification of these loci was examined in 22 related species from three subfamilies of Bromeliaceae. The transferability of these microsatellites will be helpful in conservation genetics studies in many bromeliad taxa.

\section{Results and Discussion}

\subsection{Isolation, Characterization and Cross-Amplification of Microsatellite Loci}

Nine from $20 \mathrm{D}$. distachya loci amplified robustly and proved to be polymorphic. Markers isolation involved the development of a genomic enriched library. A total of 96 positive clones were captured and 48 colonies were sequenced, of which 24 clones showed simple sequence repeats (SSR) motifs. Twenty primer pairs were designed in which the product size ranged between 100 and 300 base pairs. Nine of these primer pairs generated consistent patterns of amplification and were used for further characterization of two $D$. distachya populations. The primer sequences and product sizes are shown in Table 1. 
Table 1. Description and characterization of nine microsatellite loci of Dyckia distachya, including locus name, primer sequences, repeat motif, number of alleles (A), allele size range and GeneBank accession number.

\begin{tabular}{|c|c|c|c|c|c|}
\hline Locus & Primer Sequences $\left(5^{\prime}-3^{\prime}\right)$ & Repeat motif & $\mathbf{A}$ & Size (bp) & $\begin{array}{c}\text { GeneBank } \\
\text { accession No }\end{array}$ \\
\hline $\operatorname{Dd} 03$ & F: TAGGCAGATGCGAATTGAGT & $(\mathrm{CA})_{10}$ & 6 & $202-212$ & JX290116 \\
\hline & $\begin{array}{l}\text { R: CTCAGCATAGCTTTCGATGG } \\
\text { F: CGCTTTTCTCGGAATCTTTG }\end{array}$ & & & & \\
\hline $\operatorname{Dd} 04$ & R: AGGGCTTCGTCCTCCTAAAA & $(\mathrm{TG})_{8}$ & 6 & $227-257$ & JX290117 \\
\hline $\operatorname{Dd} 07$ & $\begin{array}{l}\text { F: GATTCGGAAGGATGACAAGA } \\
\text { R: CGGCACAGGAATACAAAGAG }\end{array}$ & $(\mathrm{GA})_{25}$ & 5 & $201-213$ & JX290118 \\
\hline $\operatorname{Dd} 08$ & $\begin{array}{l}\text { F: GATCGGTCTTTTACTCCTTGG } \\
\text { R: CACGCTAGGATGATGTAGGC }\end{array}$ & $(\mathrm{AC})_{6} \mathrm{G}(\mathrm{GA})_{9}$ & 10 & $192-232$ & JX845415 \\
\hline Dd09 & $\begin{array}{l}\text { F: ACTCTGCTGCCTCATTCACA } \\
\text { R: CACAGCAAAGGCAAACTTGA }\end{array}$ & $(\mathrm{GA})_{10}$ & 10 & $176-228$ & JX845416 \\
\hline $\operatorname{Dd} 10$ & $\begin{array}{l}\text { F: CTATGGGACTGCTGGACACT } \\
\text { R: CTTGCTGGTAATCGTGTTCC }\end{array}$ & $(\mathrm{TG})_{7}$ & 4 & $248-254$ & JX290119 \\
\hline $\operatorname{Dd} 16$ & $\begin{array}{l}\text { F: AATTGCACCAAACAGGGATT } \\
\text { R: GACACGACCCACATAGATGC }\end{array}$ & $(\mathrm{GT})_{7}(\mathrm{GC})_{4}$ & 7 & $170-190$ & JX290120 \\
\hline $\operatorname{Dd} 19$ & $\begin{array}{l}\text { F: GTGCCAAACATAAACCGATG } \\
\text { R: AACGACCAAAAAGGGTGTTC }\end{array}$ & $(\mathrm{GT})_{5}$ & 6 & $239-278$ & JX290121 \\
\hline $\operatorname{Dd} 20$ & $\begin{array}{l}\text { F: GGTGGAAATGGTGGGTTACA } \\
\text { R: GGCAGGCAAGGTATGAAGAA }\end{array}$ & $(\mathrm{CA})_{7}$ & 6 & $227-253$ & JX290122 \\
\hline
\end{tabular}

In the introduced population, the number of alleles per locus ranged from 4 to 10, with an average of 6.2, and the expected and observed heterozygosities ranged from 0.136 to 0.667 and from 0.543 to 0.877 , respectively. In the wild population, the number of alleles per locus varied from 2 to 8 , with an average of 3.8, and the expected and observed heterozygosities ranged from 0.000 to 0.895 and from 0.050 to 0.811 , respectively (Table 2). Four loci showed significant departures from the Hardy-Weinberg equilibrium (HWE) due to heterozygote deficiency in both populations (Dd04, Dd08, Dd09 and Dd20; Table 2). Such significant deviation from HWE could have been caused by the involvement of null alleles. We tested the presence of null alleles and the four loci that showed significant departures from HWE in both populations exhibited high null allele frequencies (data not shown). Other three loci showed significant departures from HWE in only one population $(p<0.001$; Table 2) and did not show null alleles, being the departures probably due to inbreeding or Wahlund effects.

Cross-species amplification was successful in different degrees (Table 3). All loci amplified in species from same genus (except Dd19 for D. maritima). Locus Dd10 and Dd20 amplified in all species tested, and locus Dd07 and Dd16 were successful in $86.3 \%$ of the species evaluated. The 12 genus tested correspond to three representative Bromeliaceae subfamilies from Atlantic Rainforest, indicating high potential for use of these four loci in phylogeography and population genetic studies of many Bromeliaceae species, mainly for Dyckia genus. 
Table 2. Results of nine microsatellite loci in two populations of Dyckia distachya, including number of individuals $(N)$, number of alleles $(A)$, observed $\left(H_{\mathrm{O}}\right)$ and expected $\left(H_{\mathrm{E}}\right)$ heterozygosities.

\begin{tabular}{lccccccc}
\hline \multirow{2}{*}{ Locus } & \multicolumn{3}{c}{ Introduced $(\boldsymbol{N}=\mathbf{2 2})$} & \multicolumn{3}{c}{ Natural $(\boldsymbol{N}=\mathbf{2 1})$} \\
\cline { 2 - 4 } \cline { 5 - 7 } & $\boldsymbol{A}$ & $\boldsymbol{H}_{\mathbf{O}}$ & $\boldsymbol{H}_{\mathbf{E}}$ & & $\boldsymbol{A}$ & $\boldsymbol{H}_{\mathbf{O}}$ & $\boldsymbol{H}_{\mathbf{E}}$ \\
\hline $\operatorname{Dd} 03$ & 6 & 0.636 & $0.724^{*}$ & 3 & 0.350 & 0.309 \\
$\operatorname{Dd} 04$ & 6 & 0.136 & $0.636^{*}$ & 3 & 0.214 & $0.659 *$ \\
$\operatorname{Dd} 07$ & 4 & 0.667 & 0.582 & 2 & 0.050 & 0.050 \\
$\operatorname{Dd} 08$ & 10 & 0.300 & $0.877^{*}$ & 7 & 0.300 & $0.720^{*}$ \\
$\operatorname{Dd} 09$ & 8 & 0.136 & $0.558^{*}$ & 8 & 0.167 & $0.811^{*}$ \\
$\operatorname{Dd} 10$ & 4 & 0.545 & 0.589 & 3 & 0.143 & 0.257 \\
$\operatorname{Dd} 16$ & 6 & 0.545 & 0.601 & 4 & 0.895 & $0.552 *$ \\
$\operatorname{Dd} 19$ & 6 & 0.182 & $0.543 *$ & 2 & 0.048 & 0.136 \\
$\operatorname{Dd} 20$ & 6 & 0.476 & $0.784 *$ & 3 & 0.000 & $0.284 *$ \\
Mean & 6.2 & 0.402 & 0.591 & 3.8 & 0.241 & 0.188 \\
\hline
\end{tabular}

* Indicates $\mathrm{H}_{\mathrm{O}}$ departed significantly from $H_{\mathrm{E}}$ under $\mathrm{HWE}(p<0.001)$.

\subsection{Genetic Diversity of D. distachya}

In our study, introduced population showed, on average, a higher number of alleles per locus, and higher observed and expected heterozygosities compared with the wild population (Table 2). The results could indicate that the individuals rescued may be representative of the original population, retaining the genetic diversity, although further studies should be made for a more accurate conclusion. The introduced population presented 25 exclusive alleles of a total 60 alleles (data not show). The wild population showed only three exclusive alleles and low genetic diversity. The microsatellites characterized here will be used to assess more thoroughly the genetic diversity of natural and introduced populations. However, one hypothesis for lower genetic diversity found in natural population would be the edge effect [5], since this population occurs at the range edge of the original geographical distribution of the species. This phenomenon has also been observed in Vriesea gigantea, another species of bromeliad [6].

\section{Experimental Section}

\subsection{Isolation of Microsatellite Markers}

To identify and characterize microsatellites, genomic DNA was extracted from fresh leaves of one D. distachya individual following the protocol of Doyle and Doyle [7]. Microsatellite markers were developed as described by Kijas et al. [8] with modifications by Billote et al. [9], using an enriched library methodology. In brief, total DNA was cleaved with the restriction enzyme RsaI (Invitrogen, Carlsbad, CA, USA). The cleaved DNA was linked to two complementary oligo adapters. Polymerase chain reaction (PCR) was performed using one of the adapters as a primer. The PCR product was purified using a QIAquick PCR Purification Kit (Qiagen, Hilden, Germany). Fragments that contained microsatellite repeats were selected using biotinylated probes $(\mathrm{dCT})_{8}$ and $(\mathrm{dGT})_{8}$ and isolated with Dynabeads M-280 Streptavidin magnetic particles (Invitrogen, Carlsbad, CA, USA). An additional 
PCR was performed using one of the adapters as a primer. The PCR products were inserted into the pGEM-T Easy vector (Promega, Madison, WI, USA) and used to transform XL1-Blue competent cells (Escherichia coli, Stratagene, La Jolla, CA, USA). Recombinant colonies were selected by blue/white screening. Ninety-six recombinant colonies were randomly selected, and 48 were double-sequenced using the BigDye Terminator version 3.1 Cycle Sequencing Kit (Applied Biosystems, Foster City, CA, USA) on an ABI PRISM 377 DNA Sequencer (Applied Biosystems, Foster City, CA, USA). Every the forward and reverse sequences obtained were aligned and edited in SeqMan (DNASTAR package, Madison, WI, USA), and primers were designed using the Primer3 program [10].

\subsection{Primer Validation}

To assess polymorphisms, 22 individuals from one $D$. distachya population introduced in Anita Garibaldi, Santa Catarina State, Brazil $\left(27^{\circ} 58^{\prime} 81^{\prime \prime S}, 50^{\circ} 39^{\prime} 11^{\prime \prime} \mathrm{W}\right)$ and 21 individuals from the wild population were genotyped. The wild population was collected in Salto do Yucumã, in Turvo State Park, Derrubadas, Rio Grande do Sul State $\left(27^{\circ} 09^{\prime} 62^{\prime \prime} \mathrm{S}, 53^{\circ} 53^{\prime} 45^{\prime \prime} \mathrm{W}\right)$, southern edge of species original distribution and the introduced population came from the ex situ collection.

For each SSR, the forward primers were synthesized with a 19-bp M13 tail (5'-CACGACGTTGTAAAACGAC-3') following the method of Schuelke [11], which involved three primers: a forward SSR-specific primer with the M13 tail at its 5' end, a reverse locus-specific primer, and a universal M13 primer labeled with one of four fluorescent dyes (6-FAM, VIC, NED, and PET; Applied Biosystems, Foster City, CA, USA). All PCR amplifications were performed in a TC-412 thermal cycler (Techne, Burlington, NJ, USA) in $10 \mu \mathrm{L}$ reactions containing $10 \mathrm{ng}$ of DNA template, $1 \times$ Taq buffer, $2 \mathrm{mM} \mathrm{MgCl} 2,200 \mu \mathrm{M}$ of each dNTP, 1 pmol forward primer, 4 pmol reverse primer, 0.4 pmol universal M13 primer, and 0.5 U Taq DNA polymerase (GoTaq; Promega, Madison, WI, USA). The touchdown cycling program was used: $95{ }^{\circ} \mathrm{C}$ for $3 \mathrm{~min}, 10$ cycles of $94{ }^{\circ} \mathrm{C}$ for $30 \mathrm{~s}, 58{ }^{\circ} \mathrm{C}$ decreasing to $48{ }^{\circ} \mathrm{C}$ at $1{ }^{\circ} \mathrm{C}$ per cycle for $30 \mathrm{~s}, 72{ }^{\circ} \mathrm{C}$ for $30 \mathrm{~s}$, followed by 30 cycles of $94{ }^{\circ} \mathrm{C}$ for $30 \mathrm{~s}$, $48{ }^{\circ} \mathrm{C}$ for $30 \mathrm{~s}$, and $72{ }^{\circ} \mathrm{C}$ for $30 \mathrm{~s}$, and concluding with a $10 \mathrm{~min}$ extension at $72{ }^{\circ} \mathrm{C}$. The microsatellite alleles were resolved on a $A B I 3100$ DNA Analyzer Sequencer (Applied Biosystems, Foster City, CA, USA) and sized against the GS500 LIZ molecular size standard (Applied Biosystems, Foster City, CA, USA) using GeneMarker DEMO version 1.97 (SoftGenetics, State College, PA, USA). The number of alleles, and expected and observed heterozygosities were analyzed with MSA 4.00 software [12], and Genepop 4.1 [13] was used to test for departure from the Hardy-Weinberg equilibrium (HWE). Null allele frequencies were calculated following [14] for each population, using the software Micro-Checker version 2.2.3 [15].

The polymorphic markers were also tested for cross-transferability in 22 related species from three subfamilies of Bromeliaceae. The PCR conditions were the same as described above. The amplification products were separated on 2\% agarose gels (Agarose LE; USB, Cleveland, OH, USA) stained with GelRed (Biotium, Hayward, CA, USA) and visualized under ultraviolet light. A locus was considered to have been amplified successfully when at least one band of the expected size was visualized. A 50-bp DNA ladder (Ludwig Biotec, Alvorada, RS, Brazil) was used as a molecular size marker. All voucher specimens of the species investigated are identified in Table S1. 
Table 3. Cross-amplification of nine microsatellite markers isolated from Dyckia distachya across three subfamilies of Bromeliaceae.

\begin{tabular}{|c|c|c|c|c|c|c|c|c|c|c|}
\hline Species & Subfamily & Dd03 & Dd04 & Dd07 & Dd08 & Dd09 & Dd10 & Dd16 & Dd19 & Dd20 \\
\hline Dyckia leptostachya & Pitcairnioideae & + & + & + & + & + & + & + & + & + \\
\hline Dyckia maritima & Pitcairnioideae & + & + & + & + & + & + & + & - & + \\
\hline Dyckia tuberosa & Pitcairnioideae & + & + & + & + & + & + & + & + & + \\
\hline Acanthostachys strobilacea & Bromelioideae & - & - & + & - & - & + & + & - & + \\
\hline Aechmea caudata & Bromelioideae & - & - & + & - & - & + & + & - & + \\
\hline Aechmea coelestis & Bromelioideae & - & - & - & - & - & + & + & - & + \\
\hline Aechmea comata & Bromelioideae & $\mathrm{w}$ & - & + & - & - & + & + & - & + \\
\hline Aechmea gamosepala & Bromelioideae & - & - & + & + & - & + & + & - & + \\
\hline Aechmea recurvata & Bromelioideae & + & - & + & - & - & + & + & - & + \\
\hline Aechmea winkleri & Bromelioideae & $\mathrm{w}$ & - & + & $\mathrm{w}$ & - & + & + & - & + \\
\hline Billbergia amoena & Bromelioideae & - & - & $\mathrm{w}$ & - & + & + & + & - & + \\
\hline Bromelia antiacantha & Bromelioideae & - & - & + & - & + & + & + & + & + \\
\hline Edmundoa lindenii & Bromelioideae & - & - & - & - & - & + & + & - & + \\
\hline Hohenbergia augusta & Bromelioideae & - & - & - & $\mathrm{w}$ & + & + & + & - & + \\
\hline Neoregelia guttata & Bromelioideae & + & - & + & + & + & + & + & - & + \\
\hline Nidularium procerum & Bromelioideae & + & - & + & + & - & + & + & $\mathrm{w}$ & + \\
\hline Quesnelia quesneliana & Bromelioideae & - & - & + & $\mathrm{w}$ & - & + & + & - & + \\
\hline Alcantarea extensa & Tillandsioideae & + & - & + & $\mathrm{w}$ & - & + & + & - & + \\
\hline Vriesea carinata & Tillandsioideae & + & - & + & - & - & + & $\mathrm{w}$ & + & + \\
\hline Vriesea gigantea & Tillandsioideae & + & - & + & - & - & + & - & - & + \\
\hline Vriesea incurvata & Tillandsioideae & + & - & + & - & - & + & - & - & + \\
\hline Vriesea reitzii & Tillandsioideae & + & - & + & - & - & + & - & - & + \\
\hline Total $=22$ & & 13 & 3 & 19 & 10 & 7 & 22 & 19 & 5 & 22 \\
\hline
\end{tabular}

Note: + = successful PCR amplification; $\mathrm{W}=$ weak PCR amplification; - = PCR failure. 


\section{Conclusions}

In the present study, microsatellite-enriched genomic library of Dychia distachya was constructed and a total of nine polymorphic microsatellite DNA markers were characterized. The development of these markers will contribute to future population genetic studies in D. distachya and other bromeliad species. The nine loci will also be useful for identifying the effects of introduction on outcrossing and selfing rates, with a comparative analysis among introduced and wild populations of $D$. distachya using progeny arrays. The use of such markers will facilitate inferences about the reproductive potential and viability of the introduced $D$. distachya populations and will aid in the understanding of the role of genetics in plant species introduction.

\section{Acknowledgments}

The authors thank the researchers M. Wiesbauer and T.G. Zimmermann for helping to collect samples; A.P. Sousa and F.W. Cidade for technical assistance during libraries construction. We also thank IBAMA (Instituto Brasileiro do Meio Ambiente e dos Recursos Naturais Renováveis) and BAESA (Energética Barra Grande S/A) for collection permits and founding this manuscript. Research was founded by CNPq (Conselho Nacional de Desenvolvimento Científico e Tecnológico), PPGBM (Programa de Pós Graduação em Genética e Biologia Molecular - UFRGS) and PRONEX-FAPERGS (Fundação de Amparo à Pesquisa do Estado do Rio Grande do Sul).

\section{Conflict of Interest}

The authors declare no conflict of interest.

\section{References}

1. Reitz, R. Bromeliáceas e a malária-Bromélia endêmica. Flora Ilustrada Catarinense; Barbosa Rodrigues Herbarium Press: Itajaí, SC, Brazil, 1983; pp. 82-85.

2. Reis, A.; Rogalski, J.; Vieira, N.K.; Berkenbrock, I.S. Conservação de espécies reófitas de Dyckia do sul do Brasil: Dyckia distachya; Technical Report; Universidade Federal de Santa Catarina: Florianópolis, SC, Brazil, 2005; pp. 3-7.

3. Wiesbauer, M.B.; Reis, A. Conservação ex situ e reintrodução de espécies na natureza: O que aprendemos nas experiências com a reófita Dyckia distachya. In Perspectivas sistêmicas para a conservação e restauração ambiental: do pontual ao contexto; Tres, D.R., Reis, A., Eds.; Barbosa Rodrigues Herbarium Press: Itajaí, SC, Brazil, 2009; pp. 355-3661.

4. MMA-Ministério do Meio Ambiente (Ministry of Environment). Normative Statement No. 6; Ministério do Meio Ambiente: Brasília, Brazil, 23 September 2008.

5. Eckert, C.G.; Samis, K.E.; Lougheed, S.C. Genetic variation across species' geographical ranges: The central-marginal hypothesis and beyond. Mol. Ecol. 2008, 17, 1170-1188.

6. Palma-Silva, C.; Lexer, C.; Paggi, G.M.; Barbará, T.; Bered, F.; Bodanese-Zanettini, M.H. Range-wide patterns of nuclear and chloroplast DNA diversity in Vriesea gigantea (Bromeliaceae), a neotropical forest species. Heredity 2009, 103, 503-512.

7. Doyle, J.J.; Doyle, J.L. Isolation of plant DNA from fresh tissue. Focus 1990, 12, 13-15. 
8. Kijas, J.M.; Fowler, J.C.; Garbett, C.A.; Thomas, M.R. Enrichment of microsatellites from the citrus genome using biotinylated oligonucleotide sequences bound to streptavidin-coated magnetic particles. BioTechniques 1994, 16, 656-660.

9. Billote, N.; Risterucci, A.M.; Baurens, F.C. Microsatellite enriched libraries: Applied methodology for the development of SSR markers in tropical crops. Fruits 1999, 54, 27-288.

10. Rozen, S.; Skaletsky, H. Primer3 on the WWW for General Users and for Biologist Programmers. In Bioinformatics Methods and Protocols in the series Methods in Molecular Biology; Krawetz, S., Misener, S., Eds.; Humana Press: Totowa, NJ, USA, 2000; pp. 365-386.

11. Schuelke, M. An economic method for the fluorescent labeling of PCR fragments. Nat. Biotechnol. 2000, 18, 233-234.

12. Dieringer, D.; Schlötterer, C. Microsatellite Analyser (MSA): A platform independent analysis tool for large microsatellite data sets. Mol. Ecol. Notes 2003, 3, 167-169.

13. Raymond, M.; Rosset, F. Genepop: Population genetics software for exact test and ecumenicism. J. Hered. 1995, 86, 248-249.

14. Brookfield, J.F.Y. A simple new method for estimating null allele frequency from heterozygote deficiency. Mol. Ecol. 1996, 5, 453-455.

15. Van Oosterhout, C.; Hutchinson, W.F.; Wills, D.P.M.; Shipley, P. MICRO-CHECKER: Software for identifying and correcting genotyping errors in microsatellite data. Mol. Ecol. Notes 2004, 4, $535-538$.

(C) 2012 by the authors; licensee MDPI, Basel, Switzerland. This article is an open access article distributed under the terms and conditions of the Creative Commons Attribution license (http://creativecommons.org/licenses/by/3.0/). 